\title{
Agathis: A Vulnerable Genus
}

\author{
Teena Agrawal* \\ Banasthali University, Rajasthan, India
}

*Corresponding author: Teena Agrawal, Banasthali University, Rajasthan, India, Tel: +91-9680724243; E-mail: tagrawal02@gmail.com

Received Date: August 09, 2017; Accepted Date: November 09, 2017; Published Date: November 12, 2017

Copyright: (C) 2017 Agrawal T. This is an open-access article distributed under the terms of the Creative Commons Attribution License, which permits unrestricted use, distribution, and reproduction in any medium, provided the original author and source are credited.

Citation: Agrawal T (2017): Agathis: A vulnerable genus. Br J Res Vol.4 No 5: 29.

\section{Abstract}

Gymnosperm is the group of the plants which are evolutionary conserved; the distribution and the assemblages of the genera's in to the orders are the representatives of the living fossils nature of the divisions. Coniferales are the plants of the great value; they have long fossil history in to the Mesozoic era. However, now all the plants have the relict distribution.

They are the sources of the timber and the other purposes. In that review articles we are trying to present some of the aspects of the on the one of the conifers entitled as the Agathis.

Keywords: Evolution; Relict; Gymnosperms; Mesozoic era; Agathis

\section{Introduction}

Gymnosperms are the plants which are fruitless trees. The seeds is naked, it is not enclosed in to the fruit from the evolution point of view these plants have the long fossil history during the Mesozoic era magnificent forest of the gymnosperms can be seen long fossil remains of the Cycadales and the conifer are the representatives of the fascinating history of the gymnosperms. In this review articles we are trying to work on one of the important gymnosperm entitled as Agathis. This is an important genus of the family Arucariaceae. It is commonly known as the kauri or dammer. The plant is an evergreen tree. All around the globe 22 species of the tree has been found. The plant group was very luxuriant in the Jurassic period. However rapid declines can be seen in the cretaceous period of the Mesozoic era $[1,2,5,6]$. In recent era there are few patches of the Agathis in different parts of the world. However, long forest of the Agathis can be found in some isolated islands of the south part of the world. Kauri forests are the dominant forest in New Zealand and in the other parts of the world. Many tribes lives in the forest for their livelihood and for other purpose $[1,2,5,6]$. In the Malaysia and in the New Caledonia and in the southern Australia long forest of the kauri has been observed. Their distribution is very relict and they are restricted to only few places of the world $[1,2,5,6]$. We have seen that recent eras of
Agathis have relict distribution. (Retrogressive evolution) (Figure 1).

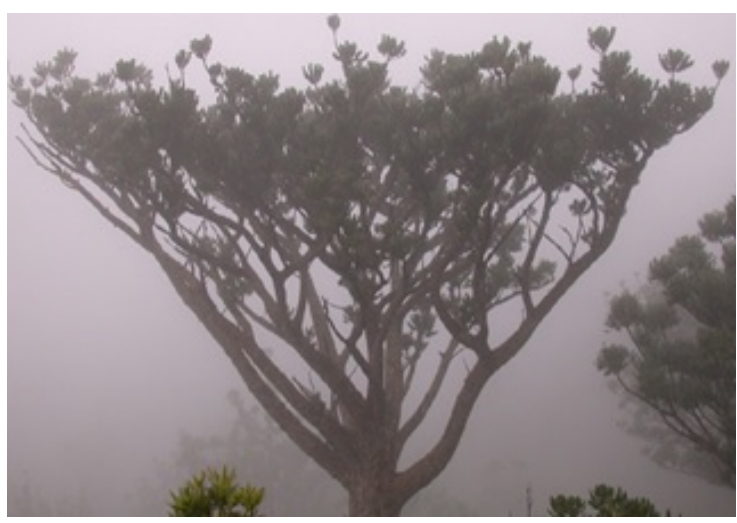

Figure 1. Agathis tree in natural habitat (Source Gymnosperm databases) [5].

\section{Habit}

The mature tree of the Agathis has a long trunk which has number of branching patterns. When the plant is young it has conical shaped $[1,2,6]$. When they are young both short and long branches form a crown on the top of the tree $[5,6]$. The leaves are small and the large, and the shape of the leavers varies from the oval to the conical shapes. In some species the leaves are the lanceolate. The shapes and the sizes of the leaves are used as the taxonomy features for the embarkation of the species of the Agathis.

The mature leaves are opposite and elliptical to linear. The young leaves are red, when they are mature they become green $[1,2,5,6]$.

The bark is smooth, the branches are horizontal and they are in ascending orders $[3,4]$.

In majority of the species the cones are on the same tree called Monoecious condition. In many cases the male cones are on the lower sides whereas the female cones can be seen on the top of the branches (Figure 2) $[3,4]$. 


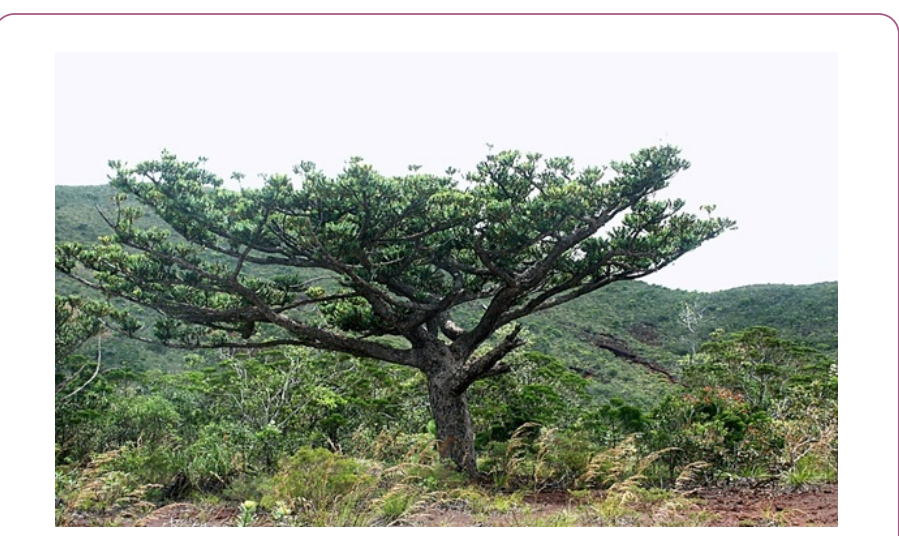

Figure 2. Agathis forest showing the dominant tree in the forest (Sources New Zealand photo).

The female cones are oval or the globose in the shape, they appear on the short branches laterally. Mode of the pollination on the Agathis is by the air but in some of the species entomophily have also been reported $[1,2,5,6]$.

Agathis had been described by various authors at different times $[1,2,5,6]$.

Some of the species of the Agathis are enlisted as:

- A. lenticuala (Borneo lasland)

- A. macrophylla (Soalman Island)

- A. macrostcys (Queensland)

- A. montana (New Caledonia)

- A. orbicualrius (Bornaeo)

- A. ovate (Borneo)

- A. phiollipensis (Phillppensis)

- A. silba (Vanata)

- A. robusta (Queenland)

- A. spatulata (Paapuea New Gunaea)

- A. zameranae (Patagonia)

- A. actopurpurea (Queensland Australia)

- A. qustralis (Nortrh Island, New Island)

- A. borneosis (Western Malasia)

- A. lanceolata (New Caledonia)

In addition to this there are few other species of the Agathis which has been reported from all over the world (Figure 3).

Phytochemical investigations is very less reported in the case of Agathis. Some of the phytochemical work has been done by Alessendro et al. They work on the Agathis robusta leaves. They utilize the chromatographic and the spectrophotometric methods for the evaluation of the leaf extract. In addition to that they utilize various methods $[1,5,6]$

Some of the uses of the Agathis are enlisted as:

- The stems and leaves of Agathis are the source of resin. The resin has various metabolites and medicinal values.
- The timber is the sources of various kind of construction. They are the main sources of the woods in the New Zealand and other islands.

- The wood is used for the formation of the guitar and the other musical instruments.

- For the home and ship building the wood is used as the main sources.

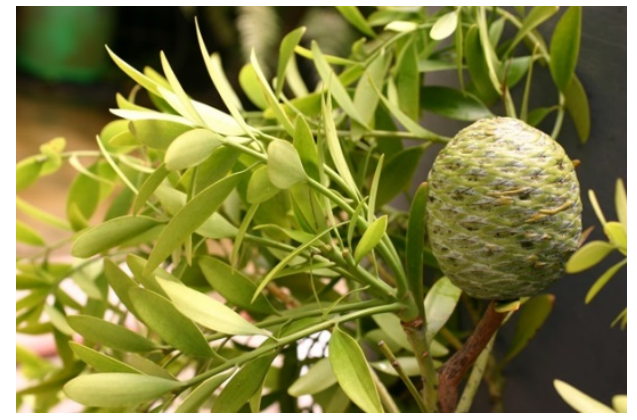

Figure 3. Agathis species female cones (sources gymnosperm databases).

\section{Conservation}

Agathis was very dominant form of the vegetation in the late Mesozoic era they have the many morphological and anatomical and cytological features of the evolutionary values. The karyotypes are also evolutionary conserved. The contents of the nucleic acid show the degeneration of the gymnosperms in the late Mesozoic, so by analyzing the nucleic acid one isolates the pathways of the gymnosperm evolution. Now days these remarkable plant of the earth are at the junction of the extinction. They are degrading and they are very restricted. IUCN has categorized the plants as endangered and near to extinction. So international efforts are needed for the conservation of the plants globally.

\section{References}

1. Farjon A (2013) Agathis robusta. The IUCN Red List of Threatened Species.

2. Kew World Checklist of Selected Plant Families.

3. Whitmore TC (1980) A monograph of Agathis. PI Syst Evol 135: 41-69.

4. Whitmore TC (1977) A first look at Agathis. Tropical Forestry Papers No. 11. University of Oxford Commonwealth.

5. Gymnosperm databases.

6. Farjon A (2013) Agathis robusta. The IUCN Red List of Threatened Species.
This article was originally published in a special issue, entitled: "Global

Research on Different Scope" 